\title{
Ostriches into Sirens: Towards an Understanding of a Septuagint Crux
}

\author{
Manolis Papoutsakis \\ Dumbarton Oaks
}

In memory of Michael P. Weitzman

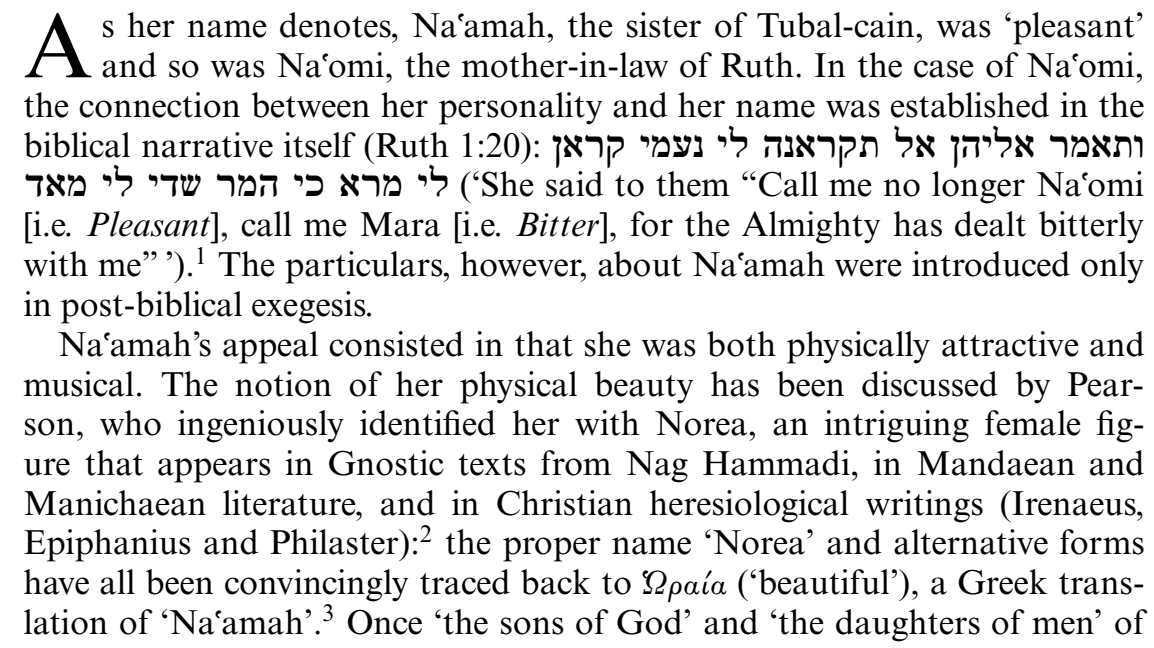

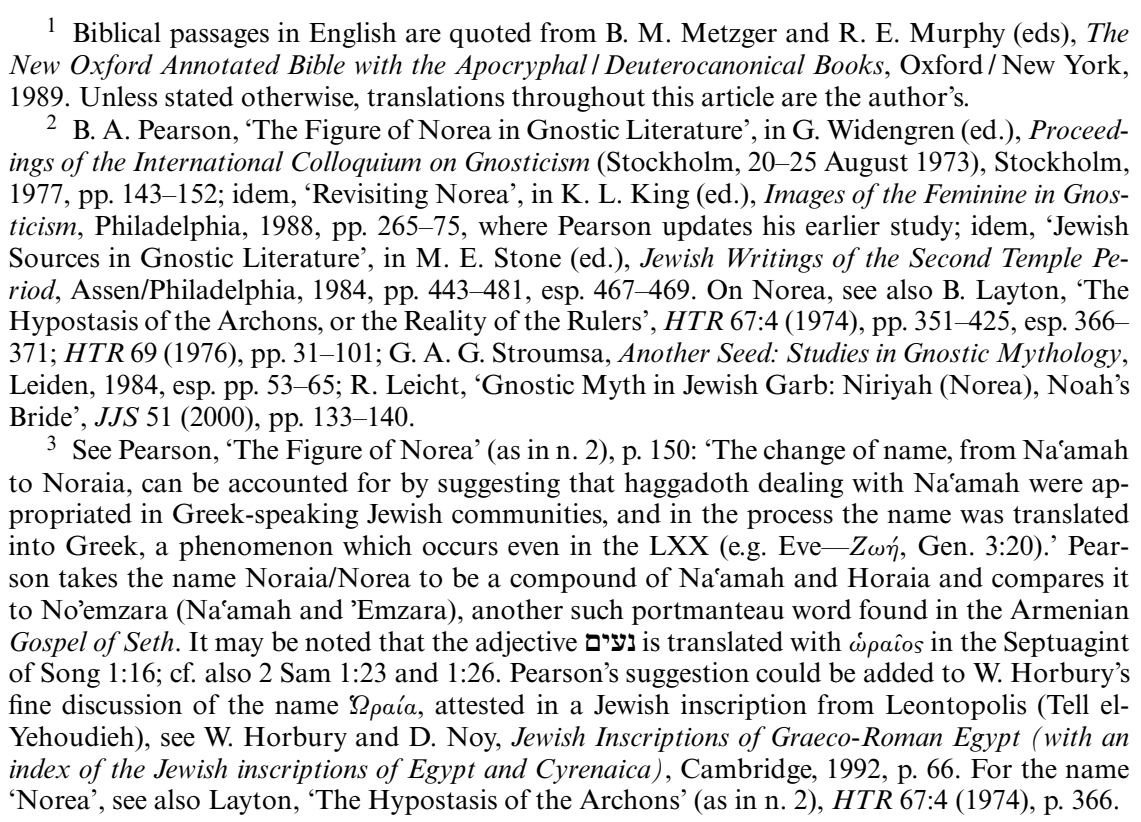


the mésalliance reported in Gen. 6:1-4 had been identified with the Sethites and the Cainites respectively, ${ }^{4}$ the Cainite Na'amah, the beautiful one par excellence, was conveniently associated with the events described at Gen. 6:2, where physical beauty and its effects are accentuated: 'the sons of God saw that they were beautiful; and they took wives for themselves of all that they chose'. ${ }^{5}$

\section{Na'amah the Siren}

nam et grammaticos, quod genus hominum praecipue, ut diximus, appetebat, eius modi fere quaestionibus experiebatur: 'Quae mater Hecubae, quod Achilli nomen inter virgines fuisset, quid Sirenes cantare sint solitae?'

Suetonius, Tiberius, 70, 3

The main theme of this article is Na'amah's mastery of song and music. Apparently, this elaboration, based on the similarity between her name and the word for 'melody' (נעימה), established Na'amah firmly in the context of Gen. 4:19-22, where members of the Cainite family are associated with the invention of crafts and music: 'Lamech took two wives; the name of the one was Adah, and the name of the other Zillah. Adah bore Jabal; he was the ancestor of those who live in tents and have live-stock. His brother's name was Jubal; he was the ancestor of all those who play the lyre and pipe. Zillah bore Tubalcain, who made all kinds of bronze and iron tools. The sister of Tubal-cain was Na'amah.'

A reference to Na'amah's musical skills is attested in Bereshit Rabbah 23:22, where her identity is disputed as follows:

$$
\text { ולמה נקראת תובל קין נעמה שמעשיה נעימים אבא רבר כהנא נעמה אמש אשת נח היית היית }
$$

\footnotetext{
4 The foundations of the identification of 'the sons of God' with the Sethites and 'the daughters of men' with the Cainites lie in Jewish exegesis, see S. P. Brock, 'Jewish Traditions in Syriac Sources', JSS 30 (1979), pp. 212-232, esp. 226 (now reprinted in S. P. Brock, Studies in Syriac Christianity, Variorum Reprints, Hampshire, 1992), and Stroumsa, Another Seed, pp. 126-134, esp. p. 131, on Josephus, Ant. 1. 69-71. We shall return to this problem at the end of this article. For a recent survey of the Christian sources, see J. C. VanderKam, '1 Enoch, Enochic Motifs, and Enoch in Early Christian Literature', in J. C. VanderKam and W. Adler (eds.), The Jewish Apocalyptic Heritage in Early Christianity, Assen/Minneapolis, 1996, pp. 60-87. I am currently working on an article that discusses Gen. 6:1-4 in Syriac tradition and is based on my D.Phil. thesis (Jacob of Serugh, The Homily on the Deluge (ll. 1-210): Introduction, Translation, and Detailed Commentary, Oxford, 2000).

5 The leading role played by Na'amah in the seduction of 'the sons of God' is discussed in both Jewish and Christian sources, cf. the tradition reported by Nachmanides on Gen. 4:22 in

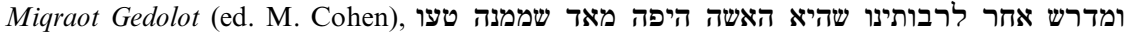

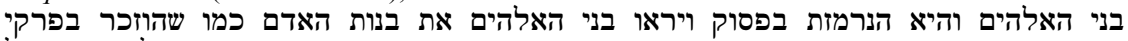

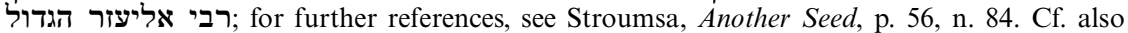
the Armenian Commentary on Genesis attributed to St Ephrem (ed. E. G. Mathews) 58:11-12:

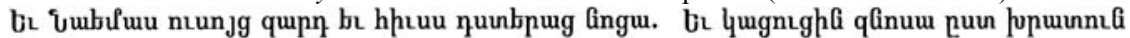
१ uufbf $\mathrm{u}_{\mathrm{J}}$ (The Armenian Commentary on Genesis Attributed to Ephrem the Syrian, transl. E. G. Mathews, C.S.C.O. vol. 573, Louvain, 1998, p. 56: 'And Na'amah taught adornment and plaiting to their daughters, and they fitted them out according to the counsel of Lamech ...').
} 


\section{שהיתה מנעמת בתוף לעבודה זרה}

'And the sister of Tubal-cain was Na'amah. R. Abba b. Kahana said: Na'amah was Noah's wife; and why was she called Na'amah? Because her deeds were pleasing (ne'imim). The Rabbis said: Na'amah was a woman of a different stamp, for the name denotes that she sang (man'emeth) to the timbrel in honour of idolatry'. 6

In the targumim, Na'amah is portrayed along the same lines as the inventor and mistress of melody and song. The Aramaic versions of Gen. 4:22 give the following expansions:

A. Ps.-Jonathan (ed. Clarke): ('And the sister of Tubal-cain was Na'amah; she was the mistress of qinin and songs')

B. Fragment-Targum (ed. Klein): וזמרין ('And the sister of Tubal-cain was Na'amah; she was the creator of qinin and songs')

C. Neofiti (ed. Díez Macho):9 ואחתה דתובל קין הות נעמה בדיה קיניין וזמרין ('And the sister of Tubal-cain was Na'amah, the inventor of qinin and songs')

With the exception of Targum Onkelos, which gives no expansion whatsoever, the Aramaic versions present Na'amah as either the 'mistress' (Ps.-Jon.), or the 'creator' (Fr.-Tg.), or the 'inventor' (Neof.) of Plthough the meaning of ממרין in straightforward (= 'songs'), the exact shade of the Aramaic of these passages seems to have been ignored by translators and lexicographers alike. Both Klein ${ }^{10}$ and Sokoloff ${ }^{11}$ imposed on the Aramaic term the nuance of its Hebrew cognate (Hebrew קינה = 'dirge'). Thus, Klein translates as follows: 'And the sister of: Tubal-cain was Na'amah; she used to

\footnotetext{
6 Text: Bereschit Rabba mit kritischem Apparat und Kommentar von J. Theodor, vol. I, Berlin, 1912, p. 224. Translation: H. Freedman and M. Simon (eds.), Midrash Rabbah, London, 1939. The identification of Na'amah with Noah's wife is a theme worth exploring in its own right; see the secondary literature cited in $\mathrm{n} .2$ above. It should be considered further in the light of a contribution by R. Mellinkoff, 'Cain's Monstrous Progeny in Beowulf, Part II: Post-Diluvian Survival', Anglo-Saxon England 9 (1981), pp. 183-197, esp. pp. 190-192, who regards this twist as 'evidence of a struggle to let some of Cain's seed survive' the Flood. On נעמה אחרת, see G. G. Stroumsa, 'Aher: A Gnostic', in B. Layton (ed.), The Rediscovery of Gnosticism. Proceedings of the International Conference on Gnosticism at Yale, New Haven, Connecticut, March 28-31, 1978, vol. II (Sethian Gnosticism), Leiden, 1981, pp. 808-818, esp. pp. 817-818.

7 E. G. Clarke with W. E. Aufrecht, J. C. Hurd and F. Spitzer, Targum Pseudo-Jonathan of the Pentateuch: Text and Concordance, Ktav Publishing House, Hoboken, New Jersey, 1984, p. 6.

8 M. L. Klein, The Fragment-Targums of the Pentateuch According to their Extant Sources, vol. I: Texts, Indices and Introductory Essays, Rome, Biblical Institute Press, 1980, p. 48.

9 A. Díez Macho, Neophyti I, Targum Palestinense; MS de la Biblioteca Vaticana, Tomo I Génesis, Edición Príncipe, Introducción General y Versión Castellana, Consejo Superior de Investigaciones Científicas, Madrid/Barcelona, 1968, p. 25.

10 Klein, The Fragment-Targums, vol. II, p. 9.

11 M. Sokoloff, A Dictionary of Jewish Palestinian Aramaic of the Byzantine Period, Bar Ilan University Press, 1990, p. 491a.
} 
compose dirges and songs'. Sokoloff, apparently following Klein whose edition he quotes, ascribes to קינין the same meaning, i.e. 'dirges'. Maher ${ }^{12}$ does the same and translates the Ps.-Jonathan passage: 'And the sister of Tubalcain; she was a composer of dirges and songs'.

On the other hand, Díez Macho, ${ }^{13}$ the editor and translator of Neofiti, renders the Aramaic original accurately: 'y la hermana de Tubal Qayin fue Naamá, la inventora de canciones y cantos'. There is, indeed, evidence that the meaning of the word in Aramaic differs from that of its Hebrew cognate. In Syriac, Rod مrimarily means 'song': in his verse homily On the Deluge, the great West Syrian poet Jacob of Serugh (d. 521) speaks of 'songs'

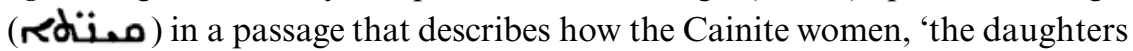
of men', seduced the Sethites, 'the sons of God': it is hardly conceivable that they would have attempted to allure the Sethites by singing dirges to them:

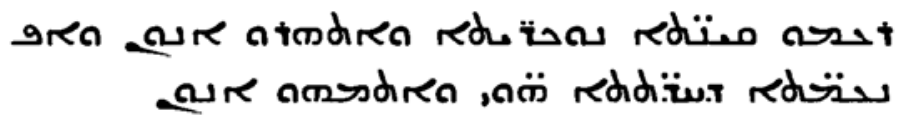

'They roared out strange songs and fascinated them as well as newfangled melodies and stupefied them'; ${ }^{\prime 4}$

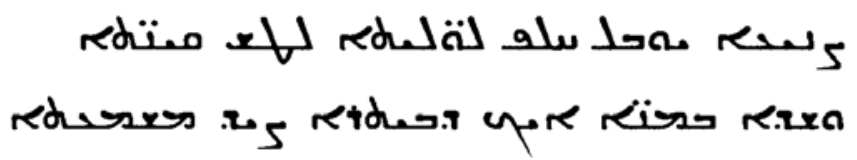

'Cunning Jubal sharpened songs instead of arrow-points and, by playing upon the strings, shot at the sense of hearing as if by pulling the bow-string'. ${ }^{15}$

In the Syriac recension of Physiologus (ed. Land), Rdu.o is used for the sweet song of the Sirens:

12 M. Maher, Targum Pseudo-Jonathan: Genesis, Edinburgh, 1992, p. 35.

13 Díez Macho, ibid., p. 24.

14 P. Bedjan (ed.), Homiliae Selectae Mar Jacobi Sarugensis (henceforth JSB), vol. 4, Paris, 1908, p. 7, 11. 12-13.

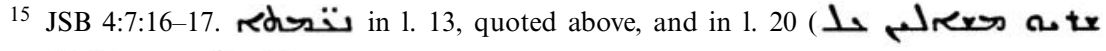

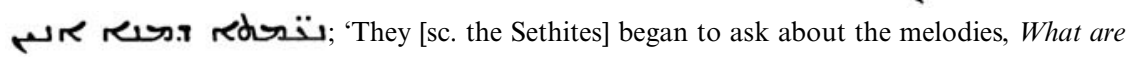
they?') may be a resonance of Na'amah (Uدم): it is a well-established fact that Syriac poets delighted in paronomasia. The same conclusion as to the neutral, if not positive, sense of Rdu. o in Jacob's writings is drawn from JSB 1:187:11, 1:190:19, 2:441:5; P. Bedjan (ed.), $S$. Martyrii, qui et Sahdona, quae supersunt omnia, Parisiis, Lipsiae, 1902, p. 782:8; J. P. Amar (ed.), Jacob of Serugh, Homily on Mar Ephrem, Critical Edition of the Syriac Text, Translation and Introduction, PO tome 47, fasc. 1, no 209, Turnhout, 1995, p. 64, couplet 153. 


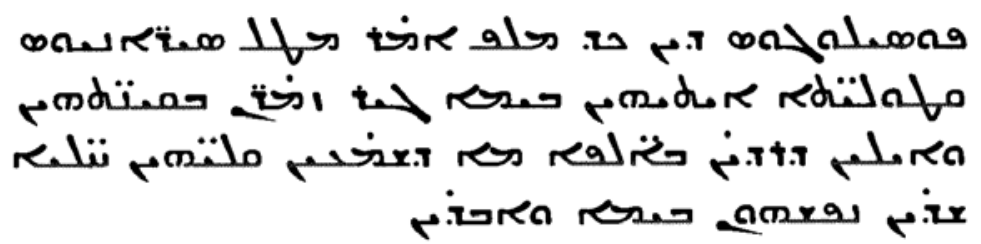

'Physiologus teaches and says about the Sirens: "They are murderers for they sing their songs at sea and those who travel by ship, when they hear their sweet voices, throw themselves into the sea and perish.", 16

In Mandaic, qinta simply means 'hymn', 'song', and none of the examples cited in the standard Mandaic Dictionary indicates any connection with mourning, e.g. brika qintaikun hilita ... d-mn pumaikun npaq ('blessed is your sweet hymn ... which proceeded from your mouths'). ${ }^{17}$ Finally, the fact that at II Chronicles 35:25 the Jewish Aramaic translator chose the term הילייתא instead in order to render Hebrew הקינות, traditionally associated in that context with the Book of Lamentations, may be said to point in the same direction. ${ }^{18}$

It appears, then, that the Aramaic term had a neutral, if not positive, meaning, while its Hebrew cognate developed the nuance 'song of lament'. Although occasionally bilingual Jews might have confused the two distinct applications, the context of Gen. 4:19-22 as well as Na'amah's involvement in the seduction of 'the sons of God' favour the sense '(alluring or sweet) songs' for קינינin the targumim. Now that this point has been clarified, I would like to suggest that the Aramaic versions ascribed consciously to Na'amah qualities of the Greek $\Sigma \epsilon \iota \rho \hat{\eta} \nu \epsilon s$, the Homeric songstresses who sat in a meadow and allured with their sweet song passing sailors to their death (Odyssey XII) ${ }^{19}$ I do not imply direct literary dependence on the Odyssey: my assumption is that the seductive Sirens had become so well-established in the folklore of the Mediterranean as to inspire such an elaboration.

\section{Sirens in the Septuagint}

Conformity to ornithological truth is no warrant for poetic felicity.

$$
\text { J. A. W. Bennett, Middle English Literature (Oxford, 1986), p. } 3
$$

Hugo Rahner discussed the symbolism of the Sirens in his celebrated book Greek Myths and Christian Mystery:

The Alexandrine translators who produced the Septuagint found six places in the ancient Hebrew books where there was mention of mysterious beasts referred to as tannim and benot yaanah, terms which mean literally jackals or hen ostriches. They render these words by the Greek $\Sigma \epsilon \iota \hat{\eta} \nu \in S$ (Sirens). What inspired

16 J. P. N. Land, Anecdota Syriaca, vol. IV, Lugduni Batavorum, 1875, p. 44.

17 E. S. Drower and R. Macuch, A Mandaic Dictionary, Oxford, 1963, p. 411b.

18 R. Le Déaut and J. Robert, Targum des Chroniques, tome II, Rome, 1971, p. 166.

19 See A. Heubeck and A. Hoekstra, A Commentary on Homer's Odyssey, vol. II (Books IXXVI), Oxford, 1989, pp. 118-120. 
this gross but most interesting mistranslation in the minds of these Hellenistic translators is a mystery which has hitherto remained unsolved. The result, however, is plain enough: for over a thousand years Greek Christians read the word 'Sirens' in the passages concerned, and the association of ideas connected with these mythical beings, so universally familiar in the folk-lore of antiquity, was sufficiently strong to arouse in the Christian Greek much the same horror that these deadly creatures had inspired in pagan forerunners and contemporaries. ${ }^{20}$

The six Septuagint passages in which $\Sigma \epsilon \iota \rho \hat{\nu} \nu \in$ ('Sirens') occur are (corresponding terms are underlined):

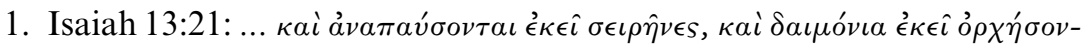

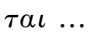

(ושכנו שם בנות יענה ושעירים ירקדו שם (MT)

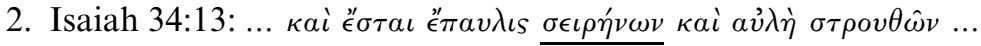
(וריתה נוה תנים חציר לבנות יענה (MT)

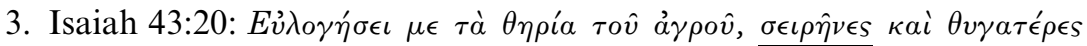
$\sigma \tau \rho \circ v \theta \hat{\omega} \nu$

(תכד (Mדני חית השדה תנים ובנות יענה (ת)

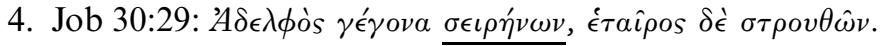

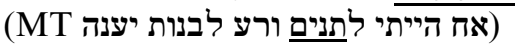

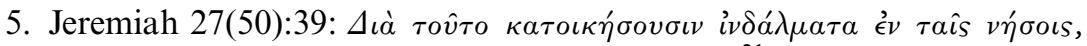

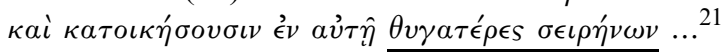

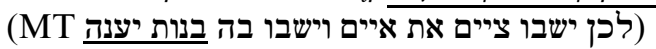

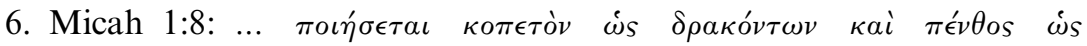

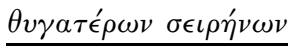

(MT אעשה מספד כתנים ואבל בבנות יענה

It has been recognised that the Septuagint betrays the translators' familiarity with Aramaic. Amid the evidence that has been regarded as pointing to this, there are Greek transliterations of Aramaic words which mirror the וקלל במלכו ומאו

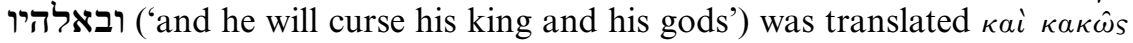

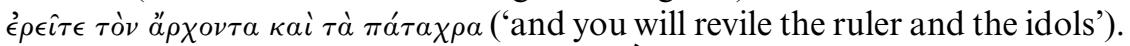
Apparently, the translator understood אלהים to mean 'idols' and glossed it with the term for 'idol' in Aramaic. Another example of this kind is found at 14:1, where $\gamma \iota \omega ́ p a s$ (Aramaic גיורא) stands for Hebrew הגר ("the proselyte'). Other aramaicisms may be the result of etymological exegesis: at Habakkuk 3:16, לקול צללו שפתי ('my lips quivered at the sound') is rendered ảò̀ $\phi \omega v \hat{\eta} s$

${ }^{20}$ H. Rahner, Greek Myths and Christian Mystery, Eng. tr. B. Battershaw, London, 1963, p. 357.

21 As has already been noted by H. Kaupel, 'Sirenen in der LXX', BZ 23 (1935-36), pp. 158165, esp. p. 159, n. 1, and H. J. Schoeps, Aus frühchristlicher Zeit. Religions-geschichtliche Untersuchungen, Tübingen, 1950, pp. 95-97, esp. 96, n. 1, the rendering $\theta v \gamma \alpha \tau \epsilon \epsilon \epsilon s \quad \sigma \epsilon \iota p \eta^{\nu} \omega \nu$ ('daughters of Sirens') in Jeremiah and Michah is a hebraism of no importance for the problem under consideration.

22 I. L. Seeligmann, The Septuagint Version of Isaiah. A Discussion of its Problems, Leiden, 1948, pp. 49-50. 
$\pi \rho o \sigma \epsilon v \chi \hat{\eta} s \chi \epsilon \iota \lambda \lambda^{\prime} \omega \nu \mu o v$ ('from the sound of the prayer of my lips'). In this case, צלל ('to quiver') was derived from Aramaic ('to pray'). ditions such as these cannot be explained unless the intermediary Aramaic term is identified.

In the targumim, the construct chain בנות יענה, found in the Hebrew origiבנת נעמיין nal of the six Septuagint passages quoted above, corresponds to (Tg. Job ברת נעמיתא): the Aramaic term for 'ostrich' is (cf. Syriac (2) a homonym to the name of Tubal-cain's sister (Gen. 4:22; cf. Tg. Ps.-Jonathan: נעמא). I would like to suggest that the 'gross but most interesting mistranslation' (Rahner) of Hebrew 'ostriches' with Greek 'Sirens' in the Septuagint may be explained as follows: at Gen. 4:22, the targumic glosses

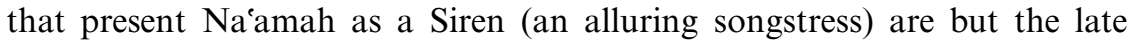
records of an early tradition that had been encouraged by the general context of Gen. 4:19-22 (on the Cainites' association with the invention of crafts and music) and had already developed before the Septuagint was undertaken. $\mathrm{Na}$ amah the Siren was subsequently associated with ostriches by means of paronomasia within the pale of a community that could operate in Aramaic: the Septuagint translators belonged to such a milieu.

There is, however, a difficulty that at first sight might thwart this attempt at explaining the crux in the Greek version. Out of the six Septuagint passages under discussion, it is only Isaiah 13:21, Jeremiah 27(50):39 and Micah 1:8 that equate 'ostriches' with 'Sirens': unless we explain the fact that at Isaiah 34:13 and 43:20, as well as at Job 30:29, the rendition $\sigma \epsilon \iota \rho \hat{\eta} \nu \in S$ corresponds not to בנות יענה ('ostriches'), but rather to תנים ('jackals'), the interpretation suggested above cannot be sustained. I shall try to show that the inconsistency does not at all affect the validity of the hypothesis that $\mathrm{Na}$ amah is concealed behind all Sirens in all six Septuagint passages; rather, it pertains to intrinsic problems of the textual transmission of the Septuagint.

Originally, differences in translation equivalents made scholars believe that the Septuagint of Isaiah, as we now have it, is the work of two different translators, i.e. one who produced chapters 1-39 and another who produced chapters $40-66 .{ }^{24}$ However, more careful analysis has shown many important similarities between the two parts which the older view, postulating multiple authorship, could not accommodate. Horizontal strata traced in the text may suggest a translator-reviser theory, as opposed to that of multiple authorship, for the two units. It seems that there was an original Greek translation which was later revised partially. Revisions of this kind have been recognised in the present textual situation of other Septuagint books as well. ${ }^{25}$

According to the textual development just described, it is suggested that בנות יענה ('ostriches') was originally translated with the term $\sigma \epsilon \iota \hat{\eta} \nu \in S$ in all three Isaiah passages under the influence of the exegetical tradition about Na'amah. This original rendering is still preserved at Isaiah 13:21, while at 34:13 and 43:20, it stands for ('jackals'), as a result of the work of a

23 E. Tov, The Text-Critical Use of the Septuagint in Biblical Research, Jerusalem, 1997, p. 179.

24 Seeligmann, The Septuagint Version of Isaiah, p. 39.

25 Seeligmann, The Septuagint Version of Isaiah, p. 40, n. 2. 
reviser who was unaware of the particular association. Moreover, the original correspondence found at Isaiah 13:21 is shared by Jeremiah 27(50):39 and Micah 1:8 (the rendering of בנות יענה with $\theta v \gamma a \tau \epsilon \in \epsilon \in$, $\sigma \epsilon \iota \rho \eta v \omega \nu$ in the last two passages supports the hypothesis that the Septuagint of Jeremiah chs. 128 was the work of the translator(s) who produced the Greek version of the Twelve Prophets). ${ }^{26}$ Job 30:29 agrees with the revised Isaiah passages. ${ }^{27}$

The discontinuity in the transmission of this subtle embroidery may be explained by the hypothesis that, as opposed to the original translator, the reviser of the Septuagint Isaiah was not at home with Aramaic: as in Greek

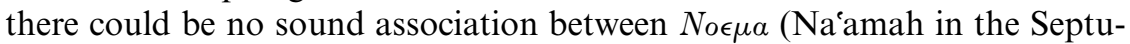
agint of Gen. 4:22) and $\sigma \tau \rho o v \theta$ òs (Greek for 'ostrich'), the original association turned into a riddle. The Greek Church Fathers, unaware of it, reset the six Septuagint passages in the context of a christianised Homeric world. ${ }^{28}$

\section{Sirens / Na amah and Lilith}

I would like to suggest that the passage into which the tradition about Na'amah the Siren was first read is Isaiah 34:13-14, where ('ostriches') occur together with לילית ('Lilith'), a hapax legomenon in the Hebrew Bible that the Septuagint rendered with óvoк'́vтаvро, a compound of

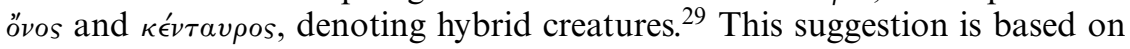
the occurrence of the pair Sirens (Na'amah)/ Liliths and the pair Na'amah (the Siren) / Lilith in later sources, to which we shall turn next. Awareness of the hybrid form of the Sirens (half birds and half women) ${ }^{30}$ could have prompted similar notions about Lilith: the term óvоќ́vтаvроs proves to be an apposite rendering of לילית ('Lilith'), who then could match Na'amah the Siren not only in function, but also in bodily form. ${ }^{31}$

26 E. Tov, The Septuagint Translation of Jeremiah and Baruch. A Discussion of an Early Revision of the LXX of Jeremiah 29-52 and Baruch 1:1-3:8, Scholars Press, Missoula, Montana, 1976, pp. 135-151, esp. p. 137.

27 In my opinion, Kaupel, 'Sirenen in der LXX' (as in n. 21), pp. 158-165, and Schoeps, Aus frühchristlicher Zeit (as in n. 21), pp. 95-97, who discussed the occurrence of Sirens in the Septuagint in the context of post-biblical Jewish demonology, missed the point.

${ }^{28}$ For the way in which the Church Fathers dealt with the problem, see Rahner, Greek Myths (as in n. 20), pp. 353-371; D. R. MacDonald, Christianising Homer: The Odyssey, Plato, and the Acts of Andrew, New York/Oxford, 1994; E. Piccini, 'Le sirene nella patristica latina', Vetera Christianorum 33 (1996), pp. 353-370. For a curious transformation of the Sirens in the East Syrian monastic writer Isaac of Nineveh (seventh cent.), see S. P. Brock, 'From Antagonism to Assimilation: Syriac Attitudes to Greek Learning', in N. G. Garsoian, T. F. Mathews and R. W. Thomson (eds.), East of Byzantium: Syria and Armenia in the Formative Period, Washington, DC, 1982, pp. 17-34, esp. p. 29 (now reprinted in S. P. Brock, Syriac Perspectives on Late Antiquity, Variorum Reprints, London, 1984).

29 As it has been explained in the preceding section ('Sirens in the Septuagint'), my hypothesis is that, prior to its revision, at Septuagint Isaiah 34:13 בשות יענה n תנים. At Isaiah 34:14, the use of the plural óvoќ́v in analogy to the plural $\sigma \epsilon \iota \rho \hat{\eta} \nu \in S$ (for the reason, see below).

${ }^{30}$ Homer does not describe the Sirens as hybrid creatures; they are presented as such in the visual arts, see Heubeck and Hoekstra, A Commentary on Homer's Odyssey (as in n. 19).

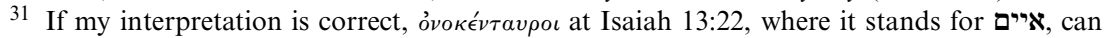
be explained as an interpretative retrojection under the influence of the tradition about the two 


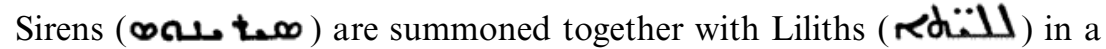
problematic passage in the Syriac Apocalypse of Baruch (II Baruch). The Syriac text was based on a Greek original, now lost, composed by a Jewish writer by the turn of the first century C.E.. The Greek text itself is believed to be a translation of a Hebrew, or Aramaic, composition. ${ }^{32}$ II Baruch 10:8 reads as follows:

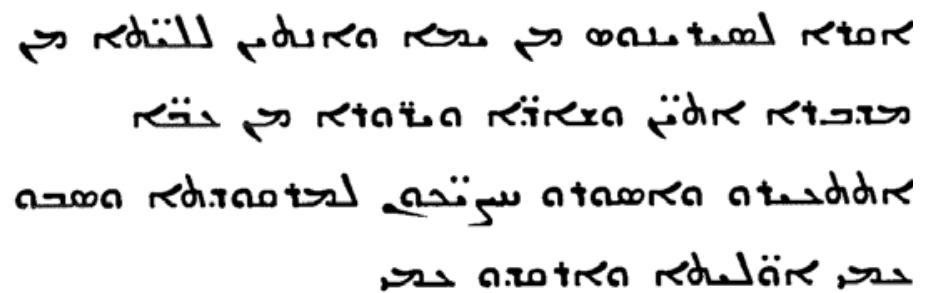

'I will summon the Sirens from the sea;

And you, Liliths, come from the desert,

And (you), demons and jackals, from the forests:

Awake and prepare yourselves for mourning,

And take up with me the dirges,

And make lamentation with me. ${ }^{33}$

According to the reconstruction of the tradition about Naamah the Siren, a Hebrew original would have read בנות נעמה ('daughters of Na'amah'), which would have been first translated into Greek as $\sigma \epsilon \iota \rho \hat{\eta} \nu \in S$ and subsequently transliterated into Syriac ( the same in the case of an Aramaic original. ${ }^{34}$

$\mathrm{Na}$ amah and Lilith occur again as a pair in the Zohar, the medieval compilation into which many early traditions were incorporated. According to $\mathrm{Zo}$ har III, 76b-77a, roaring Na'amah dwells in the tumultuous sea from where she emerges and seduces men: her roaring as well as her link with the sea may be said to identify her with the Sirens, the sea-monsters that seduced sailors with their song. The passage, which is reminiscent of elaborations on the mésalliance of Gen. 6:1-4, reads as follows:

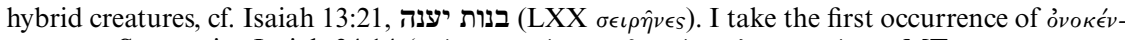

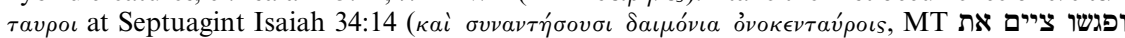

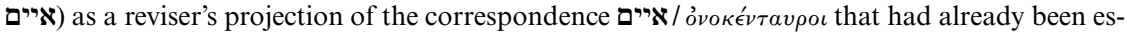

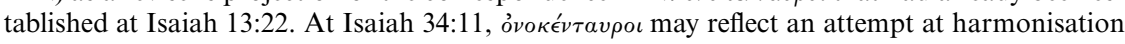
by a later reviser of the Septuagint Isaiah to whom the tradition about $\mathrm{Na}$ amah the $\sigma \epsilon \iota \rho \eta \dot{\nu}$ and Lilith the óvок'́v tavpos: demone o animale? (Dalla "nascita" biblica alla esegesi patristica)', Vetera Christianorum 35 (1998), pp. 119-131.

32 See A.-M. Denis, Introduction à la littérature religieuse judéo-hellénistique, Turnhout, 2000, tome I, pp. 746-747.

${ }^{33}$ I have adapted slightly the English translation by R. H. Charles and L. H. Brockington, in H. F. D. Sparks (ed.), The Apocryphal Old Testament, Oxford, 1984, p. 845.

34 This interpretation is in disagreement with P. Bogaert, Apocalypse du Baruch. Introduction, traduction du Syriaque et commentaire, tome I, Paris, 1969, pp. 358-359. Bogaert believes that II Baruch X, 8 depends on the Septuagint of Isaiah 34:13-14: from the perspective of this article, this is not necessary. 


$$
\begin{aligned}
& \text { וחד דכורא אשתכח דאתא לעלמא מרוחיה דסטרא דקין וקרון ליה }
\end{aligned}
$$

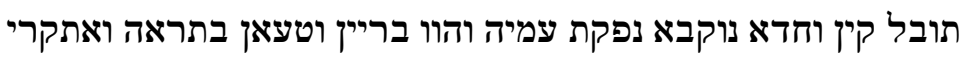

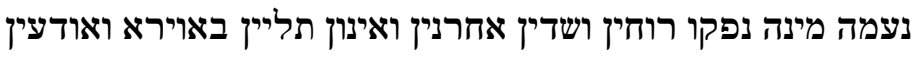

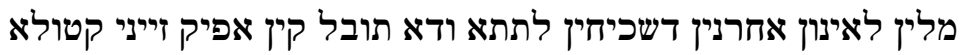

$$
\begin{aligned}
& \text { לעלמא ודא נעמה אתרגישת בריגשהא ואתדבקת בסטרהא ועד כען } \\
& \text { היא קיימא ומדורהא בין ריגשי ימא רבא ונפקת וחייכת בבני נשא } \\
& \text { ואתחממת מנייהו בחלמא בההוא תיאובתא דבר נש ואתדבקת ביה } \\
& \text { תיאובתא נטלת ולא יתיר ומההוא תיאובתא אתעברת ואפיקת זייניין }
\end{aligned}
$$

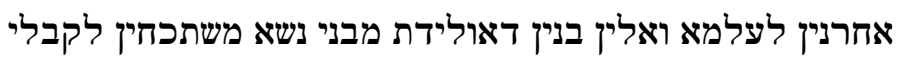

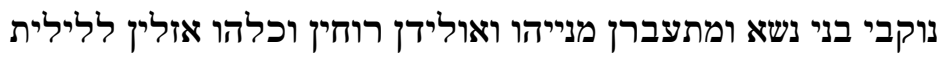

$$
\begin{aligned}
& \text { קדמיתא והיא מגדלת לון }
\end{aligned}
$$

There was a certain male who came into the world from the spirit of the side of Cain, and they called him Tubal-cain. And a certain female emerged with him, and human beings go astray after her, and she was called Na'amah. From her other spirits and demons came forth, and they are suspended in the air, giving information to others who are below. This Tubal-cain brought deadly weapons into the world. And Na amah makes a roaring noise and cleaves to her side, and she still survives. And her dwelling is among the breakers of the great sea, and she goes out and makes sport with men, warming herself on them in dreams with human desire, and cleaving to them. She receives this desire but no more, and she becomes pregnant through this desire and brings other kinds [of demons] into the world. The sons that she bears from mortal men present themselves to the females among mankind and they become pregnant by them and bear spirits. And they all go to ancient Lilith and she rears them. ${ }^{35}$

35 I have adapted the English translation by D. Goldstein, who translated the Hebrew version of I. Tishby, The Wisdom of the Zohar. An Anthology of Texts, Systematically Arranged and Rendered into Hebrew by Isaiah Tishby, Oxford, 1989, vol. II, pp. 542-543.

It may be worth considering here the medieval Armenian text that J. R. Russell translated and discussed in his article 'The Mother of All Heresies: A Late Mediaeval Armenian Text on the Yuskaparik', REArm 24 (1993), p. 273-293, esp. pp. 274-275, 'Now it is to be known what heretics are, and from whence they were bestowed. This I write in reply. As Satan spilt his poison in darkness, like Jelewson in the valley, who was crucified, so likewise did Satan conceive and beget Cain, the corrupt one, in the sea. And Cain conceived and bore Sigl, the three-headed dog, who hunted with two heads and ate greedily, insatiably, with the third. So, too, are the Manichaeans, who wished to lead the Christians astray down their own road. And then the dog Sikl [sic!] conceived and bore the Uskaparek. And the Root of Faith says concerning the Uskaparek that its head is like a dog's; its ears, like those of an ass; its snout, like [the beak] of a crane; its feet, like tubes of iron; and from the waist down, it is like a beautiful woman. It is full of the deeds of impiety, winged and sweet-voiced; and when it cries out on the sea, and puts its mouth between its [outstretched?] wings, it then calls so loudly that when sea captains hear its voice, they halt their ships in the water. And women on land abort their fetuses when they hear the sound. Now, when the accursed kings of the Persians, Ven and Vnuk, went to the hunt, they heard its voice and came to the sea captains and said, 'Brothers, hunt down that sweet-voiced, marvellous beast for us, and we will give you even half our kingdom!', Russell, ibid. p. 274-276, n. 5, suggests that Sigl (Uhq $)$, or Sikl (Uhln), may be Scylla. Is it possible that it may be instead a corrupted form of the name 


\section{Na amah in 1 Enoch?}

The puzzling occurrence of 'Sirens' in 1 Enoch 19, the last major source to be considered here, will take us back to where we started, namely the Gnostic Norea (Na'amah) discussed by Pearson and Stroumsa (see n. 2 above). In the Hypostasis of the Archons (92:18 ff.), the wicked archons attempt to rape Norea (Na'amah), who then cries out for help. In response to her plaintive cry, there comes Eleleth, one of the heavenly Illuminators, and rescues her. Pearson explained this development as 'a typically gnostic hermeneutical inversion': ${ }^{36}$ according to Jewish sources, ${ }^{37}$ the Cainite Na'amah (Gen. 4:22) played a major role in the seduction of 'the sons of God' (Gen. 6:1-4), elaborations on whose mésalliance with 'the daughters of men' in the Book of Watchers (1 Enoch 1-36) formed the basis of the Gnostic traditions about the wicked archons. Stroumsa corroborated Pearson's identification of Norea with Na'amah by drawing attention to the Midrash of Shemhazai and Azael ${ }^{38}$ and the story there of the maiden Esterah (in other sources Na'amah), ${ }^{39}$ whom Shemhazai, a leading fallen angel, tried to rape; she, however, pronounced the Tetragrammaton and ascended to heaven to turn into a star: 'the myth of Esterah/Na'amah discussed by Stroumsa shows that the theme of Na'amah's purity and her rescue from an attempted rape was already elaborated in non-gnostic Jewish tradition, perhaps as a minority opinion over against the negative interpretation of $\mathrm{Na}$ 'amah as a (Cainite) seductress', ${ }^{40}$

Is it possible to trace pure Naamah in 1 Enoch? At 1 Enoch 19:2, Uriel says of the daughters of men that the angels had seduced (cf. 1 Enoch 6): $\kappa a i$

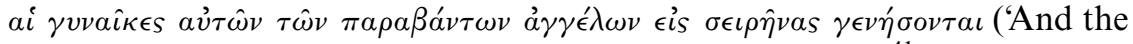
wives of these angels who transgressed shall become sirens'). ${ }^{41}$ Black was bewildered by the occurrence of 'Sirens' here: 'I have retained the Greek term. ... Could the original have been בנת נעמיין (Tg. Isa. 13:21), lit. 'daughters of loveliness', a term apparently applied to these 'desert owls' on account of their

\footnotetext{
Ut the mother of Naamah the Siren? The spelling Ubrum is attested in The Armenian Commentary on Genesis Attributed to Ephrem the Syrian, ed. E. G. Mathews, Louvain, 1998, 58:1: could a

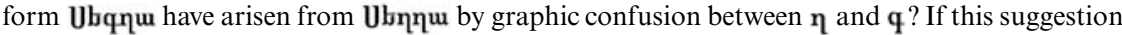
can be sustained, yet another indirect indication of the Cainite $\mathrm{Na}^{\prime}$ amah as a Siren may be discovered; for the transmission of Jewish apocryphal material to the Armenian literary tradition, see M. E. Stone, 'Jewish Apocryphal Literature in the Armenian Church', in his Selected Studies in Pseudepigrapha and Apocrypha with Special Reference to the Armenian Tradition, Leiden, 1991, pp. 3-27. On the three heads of Sigl, see also the comment by J. Grosdidier de Matons on

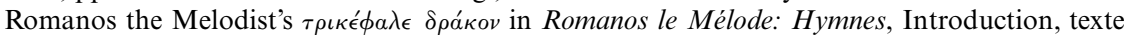
critique, traduction et notes par J. Grosdidier de Matons, tome IV, Paris, 1967, p. 525, n. 2. More about ostriches and sirens in Armenian in Ch. Dowsett, 'A Lamentation of Ostriches?', REArm 23 (1992), pp. 155-189.

36 See Pearson, 'Revisiting Norea', p. 266.

37 See n. 5.

38 For a presentation and discussion of this text, see J. T. Milik, The Books of Enoch: Aramaic Fragments of Qumran Cave 4, Oxford, 1976, pp. 321-339.

39 See Stroumsa, Another Seed, p. 56, n. 84.

40 Pearson, 'Revisiting Norea', p. 267.

41 Translation: M. Black, The Book of Enoch or 1 Enoch. A New English Edition, Leiden, 1985, p. 36 .
} 
attractive looks?'. ${ }^{42}$ I would like to suggest that, given what we know about Na'amah the Siren, Gnostic Norea, and Esterah/Naamah, it is more likely that the Aramaic original read בנת נעמא ('daughters of Na'amah'). Accordingly, 1 Enoch 19:2 appears to imply that 'the daughters of men', whom the angels forced, would be ultimately redeemed. In that case, we have in 1 Enoch the earliest trace of that minority reaction, which Stroumsa and Pearson have discussed, against the negative descriptions of $\mathrm{Na}$ amah as a seductress. If this suggestion can be sustained, Pearson's interpretation of Gnostic Norea as the result of a 'typically gnostic hermeneutical inversion' is not binding: Gnostic thinkers could have simply developed the pattern they had found in 1 Enoch. ${ }^{43}$ Finally, if Na'amah is indeed present in 1 Enoch, the identification of 'the sons of God' with the Sethites and 'the daughters of men' with the Cainites definitely has its roots in Judaism and can be dated earlier than the time of Josephus. ${ }^{44}$

42 Black, The Book of Enoch or 1 Enoch, p. 161.

43 Even the name Norea itself, which, according to Pearson (see n. 3), is based on the transla-

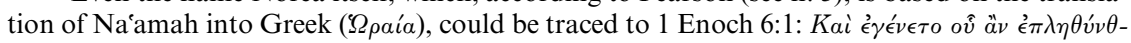

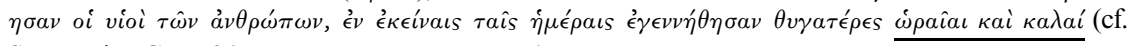

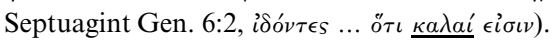

44 See n. 4. 